\title{
Effect of ammonium chloride treatment on human polymorphonuclear leucocyte iodination
}

\author{
WA PHILLIPS, CS HOSKING, MJ SHELTON \\ From the Department of Immunology, Royal Children's Hospital, Parkville, Victoria, Australia
}

SUMMARY A discontinous gradient of Percoll was used to remove RBCs from polymorphonuclear leucocyte (PMN) preparations. The resulting red blood cell-free preparation was used to investigate the effect of ammonium chloride on the iodination response of human PMN. Treatment of PMN with ammonium chloride for five minutes at room temperature resulted in a statistically significant increase in the iodination response of both resting and stimulated PMN.

Many of the methods used for isolating human polymorphonuclear leucocytes (PMN) for functional studies result in a degree of red blood cell (RBC) contamination. A common solution to this problem is to remove the RBCs by differential lysis using ammonium chloride $\left(\mathrm{NH}_{4} \mathrm{Cl}\right)$. $\mathrm{RBC}$ membranes are effectively permeable to $\mathrm{NH}_{4} \mathrm{Cl}$ and cell lysis occurs due to the unbalanced osmotic pressure of their colloid content. ${ }^{1}$

Both Boyle ${ }^{2}$ and Shortman et al ${ }^{1}$ have reported that $\mathrm{NH}_{4} \mathrm{Cl}$ treatment does not harm lymphoid cells, although Shortman et al ${ }^{1}$ warned of some damage occurring at $37^{\circ} \mathrm{C}$. A recent report that $\mathrm{NH}_{4} \mathrm{Cl}$ inhibits phagosome-lysosome fusion in murine macrophages $^{3}$ suggests that this compound may not be totally without effect on phagocytic cells. Nevertheless, in spite of the widespread use of $\mathrm{NH}_{4} \mathrm{Cl}$ to remove $\mathrm{RBCs}$ from $\mathrm{PMN}$ preparations, investigations of the effect of $\mathrm{NH}_{4} \mathrm{Cl}$ on PMN have not been reported. One of the reasons for this may be the difficulty in separating the indirect influence of $R B C$ removal from the direct effects of the $\mathrm{NH}_{4} \mathrm{Cl}$ treatment.

In this communication this problem is eliminated by using a Percoll gradient to remove the RBCs from the PMN preparation prior to treatment with $\mathrm{NH}_{4} \mathrm{Cl}$. The direct effect of $\mathrm{NH}_{4} \mathrm{Cl}$ treatment on the PMN can then be assessed in the absence of RBCs.

\section{Material and methods}

PREPARATION OF PMN

A RBC-free preparation of PMN was obtained using the method described by Phillips et al (submit-

Accepted for publication 9 March 1983 ted for publication). Briefly, $8 \mathrm{ml}$ of Ficoll-Isopaque prepared according to Boyum ${ }^{4}$ ) was layered under

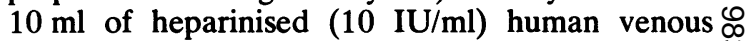
blood and centrifuged at $1500 \mathrm{RCF}$ for $15 \mathrm{~min}$. The $\omega$ upper layers containing plasma, mononuclear cells and Ficoll-Isopaque were removed and to the remaining RBC-PMN layer was added $3 \mathrm{ml} 6 \%$ 응 (wt/vol) Dextran T500 (Pharmacia, Sweden) and $10 \mathrm{ml}$ phosphate-buffered saline (PBS) $(0 \cdot 1 \mathrm{M} \stackrel{\mathbb{\complement}}{\varrho}$ sodium chloride in $0.05 \mathrm{M}$ phosphate buffer). This $\overrightarrow{\overrightarrow{\vec{B}}}$ was mixed and allowed to settle for $30 \mathrm{~min}$ after $\frac{O}{3}$ which time the PMN rich supernatant was collected. Under $20 \mathrm{ml}$ of this supernatant was layered $12 \mathrm{ml}$. of $60 \%(\mathrm{vol} / \mathrm{vol})$ Percoll solution and under that $15 \mathrm{ml} \mathrm{80 \%} \mathrm{(vol/vol)} \mathrm{Percoll} \mathrm{solution} \mathrm{(Percoll} \mathrm{solu-?}$ tion was prepared by mixing nine parts Percoll $\frac{5}{3}$ (Pharmacia) with one part 10 times concentrated PBS. This was then diluted to the appropriate concentration with single strength PBS). After centrifugation at $1200 \mathrm{RCF}$ for $10 \mathrm{~min}$ the PMN layer, $\frac{\circ}{3}$ which was found at the $60 \%-80 \%$ interface, was $>$ collected and washed three times with $20 \mathrm{ml}$ PBS by centrifugation.

The PMN preparation obtained in this way contains no mononuclear cells and minimal $(<2 \%)$ RBC contamination.

\section{AMMONIUM CHLORIDE ( $\mathrm{NH}_{4} \mathrm{Cl}$ ) TREATMENT} In each experiment the PMN purified from $60 \mathrm{ml} \stackrel{\complement}{\complement}$ venous blood were divided into eight equal portions. $\stackrel{+}{+}$ At timed intervals, duplicate portions were cen- $T$ trifuged (800 RCF, $3 \mathrm{~min}$ ) and resuspended in $\underset{\Phi}{\vec{O}}$ $10 \mathrm{ml}$ Tris-buffered (pH 7.4), isotonic $\mathrm{NH}_{4} \mathrm{Cl}$ (pre- $\stackrel{\Phi}{\square}$ pared as per Boyle ${ }^{2}$ and passed through a $0.2 \mu \mathrm{m} \stackrel{\varnothing}{\varrho}$ filter) at room temperature $\left(25^{\circ} \mathrm{C}\right)$. $\mathrm{PMN}$ were treated with $\mathrm{NH}_{4} \mathrm{Cl}$ for 5,10 and $30 \mathrm{~min}$. One set of 
duplicates was resuspended in $10 \mathrm{ml}$ PBS as an untreated control $(0 \mathrm{~min})$. The treatments were timed so that the different time intervals concluded together. All cells were then quickly washed twice with $10 \mathrm{ml}$ PBS and immediately assayed for PMN iodinating activity using the method of Pereira et al. ${ }^{5}$ Heat-killed Candida albicans and Staphylococcus aureus were used at an optical density $(540 \mathrm{~nm})$ of $1 \cdot 6$. The final concentration of phorbol myristate acetate (PMA) (Sigma Chemical Company USA) was $1 \mu \mathrm{g} / \mathrm{ml}$.

The viability of $\mathrm{PMN}$ after $\mathrm{NH}_{4} \mathrm{Cl}$ treatment was confirmed using trypan blue exclusion. ${ }^{6}$ Results were statistically analysed using the Mann-Whitney U test. ${ }^{7}$

\section{Results}

The influence of $\mathrm{NH}_{4} \mathrm{Cl}$ treatment on the iodinating ability of human PMN is seen in the Figure. Five minutes treatment was found to be sufficient to significantly $(p<0.05)$ increase the level of iodination by resting, $C$ albicans - and PMA-stimulated PMN. The magnitude of this increase was directly related to the length of time in $\mathrm{NH}_{4} \mathrm{Cl}$. $\mathrm{NH}_{4} \mathrm{Cl}$ treatment did not appear to significantly effect the $S$ aureus-stimulated PMN iodination.

PMN treated with $\mathrm{NH}_{4} \mathrm{Cl}$ retained a similar level of viability (as assessed by trypan blue exclusion) as the controls $(>95 \%)$.

\section{Discussion}

In spite of the widespread use of $\mathrm{NH}_{4} \mathrm{Cl}$ treatment to remove contaminating RBCs from PMN preparations, investigations of the effect of this compound on PMN have not, to our knowledge, been reported. One of the reasons for this may be the difficulty in separating the indirect effects of RBC lysis and removal from the direct effects of the $\mathrm{NH}_{4} \mathrm{Cl}$ treatment on the PMN. This complication arises due to the fact that the control preparation, which has not been treated with $\mathrm{NH}_{4} \mathrm{Cl}$, will contain $\mathrm{RBCs}$ while the $\mathrm{NH}_{4} \mathrm{Cl}$ treated preparation will not. This in itself may effect the results of PMN function assays. There is also the possibility that proteins and/or debris from the lysed RBCs could bind to the $\mathrm{NH}_{4} \mathrm{Cl}$ treated PMN resulting in functional alterations that are not directly related to the $\mathrm{NH}_{4} \mathrm{Cl}$.

In this study we have eliminated these problems by using a Percoll gradient to remove the vast majority of $\mathrm{RBCs}$ from the PMN preparation prior to treatment with $\mathrm{NH}_{4} \mathrm{Cl}$. In this way the effect of $\mathrm{NH}_{4} \mathrm{Cl}$ treatment on PMN is assessed in the essential absence of RBCs ( $<2 \%$ of total cells).

The results reported in this communication clearly confirm that $\mathrm{NH}_{4} \mathrm{Cl}$ treatment does have a significant effect on the iodination response of the human PMN. At room temperature 5 min treatment was sufficient to increase significantly the iodination levels of both resting and stimulated cells. Many of

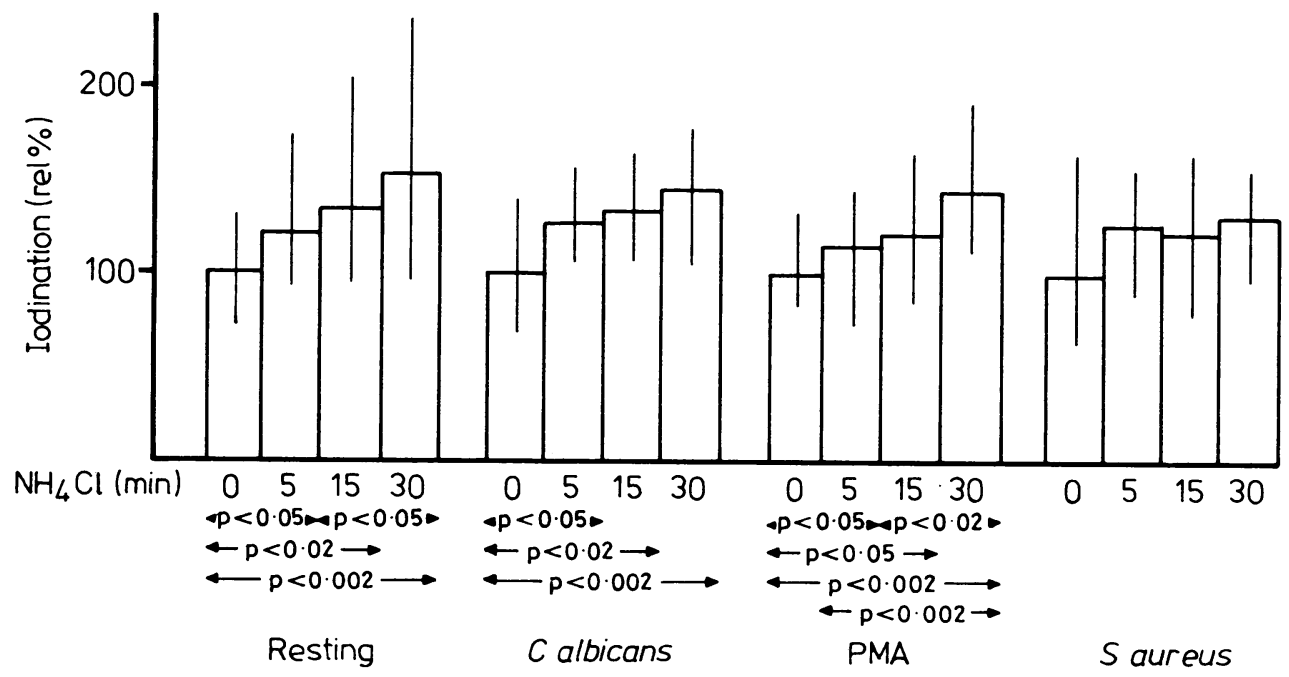

The effect of $\mathrm{NH}_{4} \mathrm{Cl}$ treatment on PMN iodination. Shown are the mean and range of three experiments in sextuplicate. To allow the comparison of data from different experiments, results expressed relative to control $(0 \mathrm{~min})$ using the formula: Rel $\%=\mathrm{cpm}($ data $) \times 100 / \mathrm{mean} \mathrm{cpm}$ of control. In a representative experiment the mean raw data for iodination by the controls was: resting $=623 \mathrm{cpm}$;

$C$ albicans-stimulated $=2765 \mathrm{cpm} ;$ PMA-stimulated $=3255 \mathrm{cpm} ;$ S aureus-stimulated $=2349 \mathrm{cpm}$ 
the reports in the literature use twice this length of time at either $4^{\circ} \mathrm{C},{ }^{18}$ room temperature ${ }^{10}$ or $37^{\circ} \mathrm{C}^{11}$ to remove RBCs. One author even suggests an $\mathrm{NH}_{4} \mathrm{Cl}$ treatment of $30 \mathrm{~min}$, or more, at room temperature for removing $\mathrm{RBCs} .{ }^{12}$

Treatment at temperatures other than room temperature or the effects of $\mathrm{NH}_{4} \mathrm{Cl}$ on other PMN functional parameters were not investigated. Five min was the shortest time tested because of technical difficulties in removing the $\mathrm{NH}_{4} \mathrm{Cl}$ in less than this time.

While this effect of $\mathrm{NH}_{4} \mathrm{Cl}$ is significant and reproducible, the mechanism involved is not clear. The $\mathrm{NH}_{4} \mathrm{Cl}$ is removed from the cells before they are assayed for iodinating activity. The observed increase in iodination is therefore not due to an influence of $\mathrm{NH}_{4} \mathrm{Cl}$ on the assay but must reflect an alteration in the activity of the PMN. Clearly further investigation is required to establish the molecular basis of this effect and to determine if other PMN functions are also influenced. In the meantime, when using $\mathrm{NH}_{4} \mathrm{Cl}$ treatment to remove $\mathrm{RBCs}$ from PMN preparations, we suggest that due consideration should be given to the possible influence of this compound.

\section{References}

' Shortman K, Williams N, Adams P. The separation of different cell classes from lymphoid organs. V. Simple procedures for the removal of cell debris, damaged cells and erythroid cells from lymphoid cell suspensions. J Immunol Methods 1972;1:273-87.

${ }^{2}$ Boyle W. An extension of the $51 \mathrm{Cr}$-release assay for the estimation of mouse cytotoxins. Transplantation 1968;6:761-4.

3 D' Arcy Hart P. Macrophage antimicrobial activity: evidence for participation by lysosomes in the killing of Saccharomyces cerevisiae by normal resident macrophages. Infect Immun 1981;31:828-30.

4 Boyum A. Isolation of mononuclear cells and granulocytes from human blood. Scand J Clin Invest 1968;21(suppl 97):77-89.

${ }^{5}$ Pereira HA, Shelton MJ, Hosking CS. Neutrophil iodination micro-method as an index of neutrophil and opsonic function. J Clin Lab Immunol 1983;(in press).

- Ford WI. The preparation and labelling of lymphocytes. In: Weir DM, ed. Handbook of experimental immunology. Oxford: Blackwell Scientific Publications, 1978:23.1.

7 Siegel S. Non-parametric statistics for the behavioural sciences. New York: McGraw-Hill Book Company Inc, 1956:116-27.

8 Dewar C. An improved method for isolation of granulocytes from peripheral blood. J Immunol Methods 1978;20:301-10.

9 Aguado MT, Pujol N, Rubiol E, Tura M, Celada A. Separation of granulocytes from peripheral blood in a single step using discontinuous density gradients of Ficoll-Urografin. A comparative study with separation by dextran.J Immunol Methods 1980;32:41-50.

${ }^{10}$ Watt SM, Burgess AW, Metcalf D. Isolation and surface labelling of murine polymorphonuclear neutrophils. J Cell Biol 1980;100:1-22.

"Simchowitz L, Spilberg I. Chemotactic factor induced generation of superoxide radicals by human neutrophils: evidence for the role of sodium. J Immunol 1979;123:2428-35.

${ }^{12}$ Wilkinson PC. Neutrophil leukocyte function tests. In: Thompson RA, ed. Techniques in clinical immunology. Oxford: Blackwell Scientific Publications, 1981:273-93.

Requests for reprints to: Dr CS Hosking, Department of Immunology, Royal Children's Hospital, Flemington Road., Parkville, Victoria, 3052, Australia. 